\title{
High diversity of cultivable heterotrophic bacteria in association with cyanobacterial water blooms
}

\author{
Katri A Berg, ${ }^{1,2}$, Christina Lyra ${ }^{1,2}$, Kaarina Sivonen ${ }^{2}$, Lars Paulin $^{3}$, Sini Suomalainen ${ }^{3}$, \\ Pirjo Tuomi ${ }^{1,4}$ and Jarkko Rapala ${ }^{1,5}$ \\ ${ }^{1}$ Finnish Environment Institute, Helsinki, Finland; ${ }^{2}$ Department of Applied Chemistry and Microbiology, \\ University of Helsinki, Helsinki, Finland; ${ }^{3}$ Institute of Biotechnology, University of Helsinki, Helsinki, \\ Finland; ${ }^{4}$ Golder Associates Oy, Helsinki, Finland and ${ }^{5}$ Department of Food and Environmental Hygiene, \\ University of Helsinki, Helsinki, Finland
}

\begin{abstract}
Cyanobacterial mass occurrences (water blooms) cause ecological, economic and health problems worldwide. Still, little is known about heterotrophic bacteria associated with cyanobacteria and the interactions between those organisms. We isolated $\mathbf{4 6 0}$ bacterial strains from more than $\mathbf{4 0}$ lakes and rivers (151 samples), Baltic Sea (32 samples) and treated drinking water of seven treatment plants (29 samples). The water bodies and the raw water of the treatment plants were frequently dominated by high numbers of cyanobacteria. Various growth media were used to isolate the strains. Analysis of partial 16S rRNA gene fragments (701-905 bp for 358 strains and 413-497 bp for 102 strains) classified the isolated bacteria as Proteobacteria, Bacteroidetes, Actinobacteria, Firmicutes and Deinococcus-Thermus. Some of these isolates represented possible new bacterial orders, families, genera or species. We isolated various potentially pathogenic bacteria, such as Aeromonas, Vibrio, Acinetobacter and Pseudomonas, that may cause adverse health effects in humans and animals and should be taken into consideration when assessing the risks caused by cyanobacterial blooms. Several strains also inhibited or enhanced the growth of cyanobacteria. Most of such strains had an enhancing effect on the cyanobacterial growth. Other isolates were affiliated with genera such as Sphingomonas or Flavobacterium, which include strains that are capable of degrading cyanobacterial toxins or other recalcitrant and problematic organic compounds. The isolated strains provide a large group of bacteria that could be used in assessing and controlling the harmful effects of cyanobacteria.
\end{abstract}

The ISME Journal (2009) 3, 314-325; doi:10.1038/ismej.2008.110; published online 20 November 2008

Subject Category: microbial population and community ecology

Keywords: bacteria; diversity; cyanobacteria; syntrophic relations; opportunistic pathogens

\section{Introduction}

Cyanobacterial mass occurrences cause problems to humans and animals. They affect recreational and domestic use of water and can also have strong physiological, chemical and biological impacts on water ecosystems, influencing, for example oxygen and light conditions, nutrient cycling and food chain composition (Sivonen and Jones, 1999; Havens, 2007; Karjalainen et al., 2007). The problems caused by cyanobacteria are often associated with the toxins that they produce as secondary metabolites and with the endotoxic lipopolysaccharide

Correspondence: J Rapala, Finnish Environment Institute, National Product Control Agency for Welfare and Health, PO Box 120, Helsinki FIN-00531, Finland.

E-mail: jarkko.rapala@gmail.com

Received 3 July 2008; revised 2 October 2008; accepted 8 October 2008; published online 20 November 2008
(LPS) structures of their cells (Sivonen and Jones, 1999; Falconer and Humpage, 2005).

Studies of cyanobacterial water blooms have usually concentrated on the cyanobacterial species composition and chemical and physical factors influencing the cyanobacterial growth (Oliver and Ganf, 2000). Little is known of the overall microbial community associated with cyanobacteria. However, various kinds of other microbes thriving among cyanobacteria may have an important impact on cyanobacterial growth or they may cause adverse health effects for humans and animals (Eiler and Bertilsson, 2004; Sigee, 2005). They can also modify the environmental effects of water blooms, such as degradation of the organic material of the bloom, which may cause oxygen depletion and subsequent fish kills (Havens, 2007).

On account of the difficulties involved in cultivating heterotrophic aquatic bacteria, bacterial 
community compositions have mainly been characterized using culture-independent methods, such as 16S rRNA gene cloning, denaturing gradient gel electrophoresis and terminal restriction fragment analysis (Kolmonen et al., 2004; Eiler and Bertilsson, 2004; Giovannoni and Stingl, 2005). However, these methods do not allow the characterization of heterotrophic bacteria in the environment.

The aim of this study was to isolate heterotrophic bacteria that occur in water bodies with frequent occurrences of cyanobacteria. For this, different growth media were formulated for the purpose of isolating putative cyanobacterial toxin degrading, cyanobacterial growth inhibiting or enhancing and potentially pathogenic bacteria. In total, 460 bacterial strains were characterized for their taxonomic properties on the basis of partial sequences of their 16S rRNA genes. The culture collection obtained consists of a wide range of earlier unknown, potentially pathogenic, cyanobacterial growth-enhancing or -inhibiting bacteria and isolates, which are closely related to known bacteria that are able to degrade recalcitrant organic compounds.

\section{Materials and methods}

Samples

Environmental samples (Supplementary data) for the isolation of heterotrophic bacteria were collected from more than 40 Finnish lakes (144 samples), 3 rivers (7 samples) and the Baltic Sea (32 samples) as well as from treated drinking water from 7 treatment plants (29 samples). The water sources were selected on the basis of the frequent occurrence of cyanobacteria in lakes, rivers and brackish water or in the water source of the treatment plants. The samples were collected when signs of cyanobacterial blooms were visually observed or microscopical analysis showed an increase in cyanobacterial cell numbers in the water bodies.

\section{Strain isolation}

For the cultivation of bacteria, $100 \mu \mathrm{l}$ of the water sample was spread on at least one of the following agar plates: Z8, R2A, CYA, TOX or BA. The Z8 agar was intended for isolation of the most oligotrophic bacteria, as it contained only mineral nutrients and no added carbon source. The plates were prepared by adding $1.2 \%$ agar to the Z8 mineral medium (Kotai, 1972). The R2A agar (Difco, Kansas City, MO, USA) was chosen as a high productivity medium for an overall view of the culturable aquatic bacteria (Massa et al., 1998). CYA agar was used for isolating bacteria that thrive in association with cyanobacteria and are possibly able to utilize the degrading cyanobacterial biomass for growth. For the CYA plates, a non-toxic cyanobacterial strain Anabaena $748 \mathrm{~A}$ was grown in a nitrogen-free Z8 medium at $20 \pm 2{ }^{\circ} \mathrm{C}$ and the culture was frozen when sufficient growth was achieved. The plates were prepared by adding agar to yield a final $1.2 \%$ (w/v) concentration of thawed Anabaena 748A culture. The mixture was autoclaved $\left(121^{\circ} \mathrm{C}\right.$, $20 \mathrm{~min}$ ) and cooled to $45^{\circ} \mathrm{C}$. As bacteria using cyanobacterial biomass for their growth, such as actinobacteria (Webster et al., 2001; Eiler and Bertilsson, 2004) often grow slowly, $10 \mathrm{mg} \mathrm{l}^{-1}$ cycloheximide, nystatin and nalidixic acid were added to prevent the growth of yeasts, fungi and fast-growing Gram-negative bacteria. These additions were used to allow longer incubation times for obtaining slowly growing bacteria. TOX agar was intended for isolating bacteria that might prefer the toxic cyanobacterial biomass for their growth and for the isolation of bacteria that possibly degrade microcystins, the cyanobacterial hepatotoxins. The TOX plates were prepared according to Lahti et al. (1998) by adding the fractionated extract (approximately $8 \mathrm{mg} \mathrm{l}^{-1}$ ) of demethyl variants of microcystin RR from the cyanobacterial strain Microcystis aeruginosa 205 to an autoclaved $\left(121^{\circ} \mathrm{C}, 20 \mathrm{~min}\right)$ and cooled $\left(45^{\circ} \mathrm{C}\right) \mathrm{Z} 8$ growth medium using the sterile filtering method. BA plates were blood agar (Base; Fluka, Deisenhofen, Germany) plates with defibrinated sheep blood (bioTRADING Benelux BV, Mijdrecht, The Netherlands), and they were used for isolating putative pathogenic bacteria living in association with cyanobacteria.

All agar plates were incubated in the dark at $20 \pm 2{ }^{\circ} \mathrm{C}$ for 7 days (Z8, R2A, CYA and TOX) or at $36 \pm 2{ }^{\circ} \mathrm{C}$ for $21 \pm 3 \mathrm{~h}$ (BA). Bacterial colonies were picked from the plates and purified further on R2A plates. From the BA plates, primarily haemolytic colonies were chosen, whereas from the Z8, R2A, CYA and TOX plates, colonies were picked more randomly, taking into account the morphological features and the colour of colonies. The isolated cultures were subcultured until pure strains were obtained. The purity of the strains was assessed by a microscopic examination of Gram-stained cells. The pure strains were stored at $-70^{\circ} \mathrm{C}$ in skimmed milk (Difco) tubes $(1.5 \mathrm{ml}$ of deionized water and $20 \%$ skim milk, autoclaved at $115^{\circ} \mathrm{C}$ ).

\section{Effect of bacterial isolates on cyanobacterial growth} The effect of selected isolated bacterial strains (184 strains) on the growth of cyanobacteria was examined using a non-toxic cyanobacterial strain Anabaena PCC 7122 and a microcystin-producing strain Microcystis PCC 7941. Both strains were obtained from the culture collection of the Institut Pasteur (http://www.pasteur.fr/ip/index.jsp). The cyanobacteria were grown in liquid Z8 mineral medium, Microcystis PCC 7941 with nitrogen and Anabaena PCC 7122 without nitrogen at $20 \pm 2{ }^{\circ} \mathrm{C}$ in a $12 / 12$-h light/dark cycle. After visible growth, $100 \mu \mathrm{l}$ of the culture was plated in soft agarose $(0.2-0.3 \%)$ on Z8 
mineral medium (1.2\% agar) as described by Rouhiainen et al. (1995). The plates were incubated at $20 \pm 2{ }^{\circ} \mathrm{C}$ in a $12 / 12$-h light/dark cycle until visible cyanobacterial growth on the plates was achieved. The heterotrophic bacterial isolates were grown in the dark in liquid R2 medium at $20 \pm 2{ }^{\circ} \mathrm{C}$ for $24-72 \mathrm{~h}$ until sufficient growth was observed. A drop (about $20 \mu \mathrm{l}$ ) of the culture was pipetted onto the agar plates with the cyanobacterial layer. The plates were incubated at $20 \pm 2{ }^{\circ} \mathrm{C}$ in the light/dark cycle, and the effect on the cyanobacterial growth was assessed visually after 1 and 2 weeks. Several strains were screened on the same plate, and a drop of R2 medium was used as a blank control on each plate. Bleaching of the cyanobacterial cells to pale green was considered as a weak effect, bleaching of the cells to yellow as a clear effect and a plaque induced by the bacterial strain as a strong inhibitory effect on the growth of cyanobacteria. Enhancement of the growth of cyanobacteria was also classified into three degrees: weak (slightly darker green cells), clear (intense dark green cells) and strong (colonylike growth of cyanobacteria).

\section{DNA isolation and sequencing}

For isolation of the DNA, the bacterial strains were grown on R2A plates at $20 \pm 2{ }^{\circ} \mathrm{C}$ until sufficient cell biomass was obtained. Bacterial cells were suspended in distilled water and boiled. After centrifugation, 5-10 $\mu \mathrm{l}$ of the pellets was taken for PCR amplification using the primers $\mathrm{pA}$ and $\mathrm{PH}$ ' or $\mathrm{pA}$ and $\mathrm{pE}^{*}$ (Edwards et al., 1989). The PCR products obtained were purified using Montage 96-well PCR purification plates, and the 16S rRNA genes of the strains were partially sequenced (701-905 bp for 358 strains and 413-497 bp for 102 strains) using BigDye terminator chemistry and analyzed on an ABI 3130 automated DNA Sequencer.

The acquired 16S rRNA gene sequences with poor quality (more than two unknown bases) were rejected for further analyses. In total, good-quality sequences were obtained for 460 isolates. The sequence data have been submitted to the EMBL database under accession numbers from AM988866 to AM989325.

\section{Sequence analysis}

The partial 16S rRNA sequences were analyzed for taxonomic hierarchy using the Ribosomal Database Project (RDP) II classifier tool (Naïve Bayesian rRNA Classifier) with annotated sequences (Wang et al., 2007). The RDP II classifier provides a rapid and accurate taxonomic placement down to the genus level for 16S rRNA gene sequences of $400 \mathrm{bp}$ and above. A bootstrap value of $80 \%$ was set as the confidence threshold for the taxonomic assignments. Each isolated strain was assigned to the lowest taxonomic hierarchy above the confidence threshold of $80 \%$. The closest sequences for the strains that could be classified only to the class or family level (22 strains) were searched from the GenBank data using the Seqmatch tool (Cole et al., 2007) of the RDP (release 10). The data set options in the Seqmatch searches were type strain and nontype strain, uncultured and isolates, above and below 1200 sequence size, nomenclatural taxonomy and 20 matches per sequence. The Basic Local Alignment Search Tool (BLAST) (Altschul et al., 1990) of the National Center for Biotechnology Information was also used to obtain taxonomic information based on the partial 16S rRNA gene sequences. In addition, the taxonomic hierarchies of the closest BLAST hits of the 16S rRNA sequences were analyzed using the RDP classifier tool to confirm the taxonomic assignments.

\section{Results}

Taxonomic assignment of the isolated strains

On the basis of the taxonomic assignment according to the RDP II classifier, the characterized 460 strains belonged to 8 different bacterial classes from 5 different phyla (Figure 1a). The majority of the strains were Gammaproteobacteria (195 strains), Alphaproteobacteria (100 strains) and Betaproteobacteria (55 strains). The rest of the strains were assigned to Actinobacteria, Flavobacteria, Sphingobacteria, Deinococci and Bacilli. Most of the strains (438 strains) could be assigned to a specific genus with a classification threshold above $80 \%$ (Figures 1b-h). The spectrum of different genera was greatest within the classes Alphaproteobacteria (13 genera), Betaproteobacteria (13 genera), Actinobacteria (9 genera) and Gammaproteobacteria (7 genera). For the classes Actinobacteria, Flavobacteria, Sphingobacteria, Bacilli and Gammaproteobacteria, there was one predominant genus (Figures 1b-e and h). With the Alphaproteobacteria and Betaproteobacteria, the strains were distributed fairly evenly into the different genera (Figures if and $\mathrm{g}$ ).

Five of the represented classes (Actinobacteria, Flavobacteria, Alphaproteobacteria, Betaproteobacteria and Gammaproteobacteria) included in total 22 strains that were not classified to the genus level and may thus represent new bacterial genera not yet validly described (Table 1). The Seqmatch searches showed that the closest matches for the sequences of these strains were derived from bacteria that had earlier not been isolated (13 strains) or described (9 strains). The environments and the geographic distribution of the closest matches varied a lot. The strains HE25, HE26 and HE72 may belong to the genus Enterobacter, because among the 20 best Seqmatch hits, there existed several Enterobacter sequences with high score values (data not shown). Three of the strains (KU10, KU14 and TA3A) were assigned only to a class level by the RDP II classifier and could therefore represent new bacterial orders 

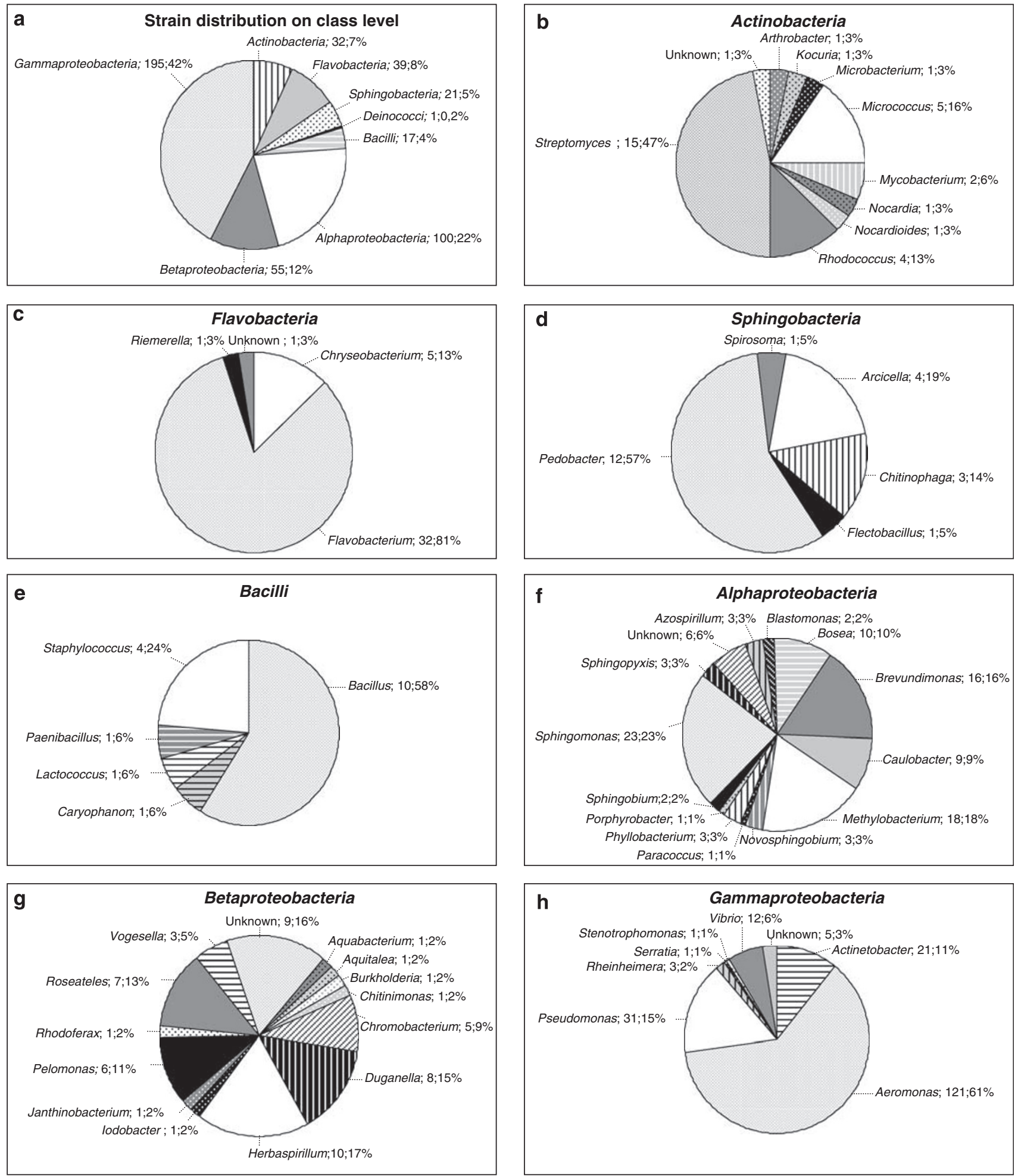

Figure 1 The proportions of taxonomic groups represented by the bacterial strains isolated from fresh and brackish water samples, and from the treated drinking water. The sequences of the bacteria were assigned to class (a) and genus level (b-h) using the RDP II taxonomic classifier. A bootstrap value of $80 \%$ was used as the default threshold. The class Deinococci included only one strain and is therefore not shown as a separate pie. The number of the isolated strains and their percentage per the taxonomic group is given together with the genus or class.

of Alphaproteobacteria and Betaproteobacteria. Furthermore, a total of 50 strains classified to the genus level had less than $98.7 \%$ maximum identity with their closest BLAST hits (Table 2). They belonged to 17 different genera, the most highly represented groups being Sphingomonas (10 
Table 1 Closest RDP Seqmatch hits for the bacterial strains that were classified only to a class or family level by RDP taxonomic classifier using a bootstrap value of $80 \%$ as the classifier threshold

\begin{tabular}{|c|c|c|c|c|}
\hline \multicolumn{2}{|c|}{ Strain } & \multicolumn{3}{|r|}{ Closest sequence } \\
\hline $\begin{array}{l}\text { Class } \\
\text { Code }\end{array}$ & Family & Accession number & Score & Source \\
\hline \multicolumn{5}{|c|}{ Actinobacteria } \\
\hline RU14 & Microbacteriaceae & EF701590 & 0.950 & Uncultured from arid soil \\
\hline \multicolumn{5}{|c|}{ Alphaprotebacteria } \\
\hline KU10 & - & DQ065552 & 0.857 & Uncultured from freshwater \\
\hline TA3A & - & EF702901 & 1.000 & Uncultured from human gastrointestine \\
\hline TA7 & Acetobacteraceae & AY345392 & 0.907 & Isolate from lake water (Hawaii, USA) \\
\hline TA7A & Sphingomonadacaeae & AY038698 & 0.968 & Uncultured from river epilithon \\
\hline RA2 & Sphingomonadacaeae & AJ250435 & 0.965 & Isolate from established aquatic biofilm (UK) \\
\hline RN19 & Sphingomonadacaeae & AJ250435 & 1.000 & Isolate from established aquatic biofilm (UK) \\
\hline \multicolumn{5}{|c|}{ Betaproteobacteria } \\
\hline KU14 & - & AY509460 & 0.968 & Uncultured from lake bacterioplankton (Sweden) \\
\hline KU8 & Alcaligenaceae & AF141422 & 0.985 & Uncultured from river water (USA) \\
\hline JO111 & Incertae sedis 5 & AM991365 & 0.950 & Uncultured from Arctic lake (Svalbard, Greenland) \\
\hline JO21 & Oxalobacteriaceae & AJ575690 & 0.973 & Uncultured from lake water enrichment (Germany) \\
\hline JO53 & Oxalobacteriaceae & AJ884745 & 0.992 & Uncultured from three-phase biofilm \\
\hline KU1 ${ }^{\mathrm{a}}$ & Oxalobacteriaceae & AJ884745 & 0.947 & Uncultured from three-phase biofilm \\
\hline JO113 ${ }^{\mathrm{a}}$ & Oxalobacteriaceae & AJ884745 & 0.947 & Uncultured from three-phase biofilm \\
\hline KK7 & Oxalobacteriaceae & AY989480 & 0.949 & Uncultured from soil (Ảlaska, USA) \\
\hline RN12 & Oxalobacteriaceae & AY345556 & 0.918 & Isolate from lake water (Hawaii, USA) \\
\hline \multicolumn{5}{|c|}{ Flavobacacteria } \\
\hline HE91 & Flavobacteriaceae & AJ876659 & 0.953 & Isolate from river sediment (Alcanema, Portugal) \\
\hline \multicolumn{5}{|c|}{ Gammaproteobacteria } \\
\hline HE25 & Enterobacteriaceae & AJ489343 & 1.000 & Isolate from freshwater sediment \\
\hline HE26 & Enterobacteriaceae & СР000653 & 1.000 & Isolate, origin unknown \\
\hline HE72 & Enterobacteriaceae & EU307101 & 1.000 & Uncultured from soil \\
\hline HE58 & Enterobacteriaceae & DQ288876 & 0.990 & Isolate from apples (Ontario, Canada) \\
\hline $4218 \mathrm{~F}$ & Vibrionaceae & DQ314527 & 0.955 & Isolate from Scopthalmus maximus \\
\hline
\end{tabular}

Accession number, score (the number of unique oligomers shared between the query sequence and a RDP sequence divided by the lowest number of unique oligos in either of the two sequences) and source of the closest Seqmatch hits are shown. -, the strain could not be classified to family level.

aThe sequences of the strains KU1 and JO113 were identical.

strains), Flavobacterium (8 strains) and Roseateles (6 strains).

Selectivity of the growth media

The bacterial strains isolated from the R2A, CYA and TOX plates belonged to a wide range of different genera, indicating lower selectivity compared with the BA and Z8 plates (Figure 2). From the R2A plates, 28 different genera were isolated, whereas the CYA and TOX plates gave 27 and 29 different genera, respectively. From the R2A and CYA plates, different genera were obtained quite evenly. The genus Flavobacterium comprised $33 \%$ of the strains isolated from the TOX plates. On the class level, the TOX plates were the most unselective, supporting bacteria from all eight classes isolated in this study, whereas approximately half of the strains from R2A $(51 \%)$ and CYA $(46 \%)$ media belonged to the Alphaproteobacteria.

From the BA plates, primarily haemolytic colonies were selected for further analyses. Overall, 133 haemolytic colonies were isolated from the plates
(Supplementary data). The genus Aeromonas comprised $61 \%$ of the bacterial strains from the BA plates (Figure 2). The genera Pseudomonas (10\%), Acinetobacter $(8 \%)$ and Vibrio $(6 \%)$ were also well represented. On a higher taxonomic level, bacterial strains isolated from the BA plates were mainly assigned to the Gammaproteobacteria (94\%). The oligotrophic Z8 medium was quite selective. The number of samples plated on Z8 and the number of strains isolated from these plates were lower than from the other plates, but of the 10 strains isolated 4 belonged to the genus Rhodococcus.

Taxonomic distribution of the strains in relation to the sample origin

The use of different growth media was also reflected on the taxonomic distribution of the bacterial strains originating from different types of water samples. The clearest difference between the different water sample types was seen in the distribution of the Vibrio and Aeromonas strains (Supplementary data). Vibrio strains were isolated only from brackish water 
Table 2 Bacterial strains isolated from fresh or brackish water samples, or treated drinking water, that may represent new bacterial species not isolated previously

\begin{tabular}{|c|c|}
\hline Strains & Class and genus \\
\hline $\begin{array}{l}\text { JO7 } \\
\text { KK2-3, KU12, RJ1, TE25, TE40, JO5, JO15 }\end{array}$ & $\begin{array}{l}\text { Flavobacteria } \\
\quad \text { Chryseobacterium } \\
\text { Flavobacterium }\end{array}$ \\
\hline $\begin{array}{l}\text { OT2, TE7, TE29, JO107 } \\
\text { RU12 }{ }^{\mathrm{a}} \text {, JO14a , JO108 } \\
\text { LI1 } \\
\text { TA2, JO45 } \\
\text { JO115 }\end{array}$ & $\begin{array}{l}\text { Sphingobacteria } \\
\text { Arcicella } \\
\text { Chitinophaga } \\
\text { Flectobacillus } \\
\text { Pedobacter } \\
\text { Spirosoma }\end{array}$ \\
\hline RU1 & $\begin{array}{l}\text { Deinococcus- } \\
\text { Thermus } \\
\text { Deinococcus }\end{array}$ \\
\hline $\mathrm{ES}^{\mathrm{a}}, \mathrm{ES}^{\mathrm{a}}$ & $\begin{array}{c}\text { Firmicutes } \\
\text { Bacillus }\end{array}$ \\
\hline $\begin{array}{l}\text { TA3 } \\
\text { HV2, LO8, RA5, RA7, RN2, SL7, TA2A, } \\
\text { TU3, TU6, VA4 }\end{array}$ & $\begin{array}{l}\text { Alphaproteobacteria } \\
\text { Methylobacterium } \\
\text { Sphingomonas }\end{array}$ \\
\hline $\begin{array}{l}\text { JO22, JO73, TA4 } \\
\text { HA5 } \\
\text { TE4 } \\
\text { IJ3 }^{\text {a }}, \mathrm{JO}^{2} 7^{\mathrm{a}}, \mathrm{JO} 96^{\mathrm{a}}, \mathrm{JO} 97^{\mathrm{a}}, \mathrm{KU} 4, \mathrm{KU} 7\end{array}$ & $\begin{array}{l}\text { Betaproteobacteria } \\
\quad \text { Duganella } \\
\text { Herbaspirillum } \\
\text { Rhodoferax } \\
\text { Roseateles }\end{array}$ \\
\hline $\begin{array}{l}\text { HE55, HE120 } \\
\text { 4218A, 4218G, TE32 }\end{array}$ & $\begin{array}{l}\text { Gammaproteobacteria } \\
\text { Acinetobacter } \\
\text { Rheinheimera }\end{array}$ \\
\hline
\end{tabular}

Abbreviation: RDP, Ribosomal Database Project.

These strains were assigned to the genus level by the RDP II taxonomic classifier but had less than a $98.7 \%$ maximum hit result with their closest BLAST hits. This indicates a lack of close relatives on the species level, based on the current 16S rRNA gene sequence similarity threshold between species (Stackebrandt and Ebers, 2006). The class and genus assigned by the RDP classifier are indicated. A bootstrap value of $80 \%$ was used as the classification threshold.

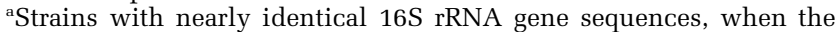
acquired sequences were aligned and cut to the same length: RU12 and JO14 (99.9\% similarity), ES2 and ES8 (99.9\% similarity), IJ3 and JO87 (99.8\% similarity), IJ3 and JO96 (99.9\% similarity) and IJ3 and JO97 (99.9\% similarity).

samples, whereas Aeromonas strains were commonly isolated from both fresh and brackish water samples. Neither of these genera were isolated from the treated drinking water. Strains of the class Alphaproteobacteria, including genera such as Sphingomonas, Brevundimonas and Methylobacterium, comprised the majority $(57 \%)$ of the strains isolated from the drinking water.

Effects of the heterotrophic bacteria on the growth of cyanobacteria

Strains from different taxonomic groups were screened for their ability to inhibit or enhance cyanobacterial growth. In total, 110 of 183 strains tested either enhanced or inhibited the growth of the toxic Microcystis PCC 7941 or the non-toxic Ana- baena PCC 7122 cyanobacterial strains (Table 3). The growth of one or both of the cyanobacterial strain was enhanced by 89 strains $(48 \%)$ and inhibited by 19 strains (10\%). One strain (Herbaspirillum JO59) inhibited the growth of non-toxic Anabaena PCC 122 cyanobacterial strain and enhanced the growth of toxic Microcystis PCC 7941, whereas another strain (Sphingomonas LI2) had the opposite effect. The heterotrophic bacterial strains inhibiting and/or enhancing the growth of cyanobacteria belonged to several different genera. The isolates represented all of the eight classes detected in this study.

\section{Discussion}

The bacterial strains (total of 460 strains) identified from cyanobacterial water bloom samples or from treated drinking water of treatment plants with frequent occurrence of cyanobacteria in the raw water represented a wide range of specific bacteria. Several strains were potential new bacterial taxa, a large number of the strains either inhibited or enhanced the growth of cyanobacteria, some strains belonged to bacterial groups that are known opportunistic human and animal pathogens and others were closely related to bacteria that are able to degrade recalcitrant organic compounds, including cyanobacterial toxins. On the basis of this study, the specifics and implications of these associations remain largely unknown, but isolation of such strains gives an opportunity to study functional significances of such associations more in detail.

The isolates were distributed into five different phyla, namely Proteobacteria, Bacteroidetes, Actinobacteria, Firmicutes and Deinococcus-Thermus. The majority of the characterized strains belonged to the phylum Proteobacteria. These taxonomic groups are commonly detected in freshwater environments (Kerters et al., 2006). In addition, strains were isolated from the phyla Bacteroidetes and Actinobacteria that have commonly been detected in freshwater microbial communities in culture-independent studies based on 16S rRNA gene analysis (Zwart et al., 2002; Eiler and Bertilsson, 2004; Kolmonen et al., 2004). In contrast, no representatives of the phylum Verrucomicrobia, which has frequently been observed by culture-independent methods (Hedlund et al., 1997; Eiler and Bertilsson, 2004; Kolmonen et al., 2004), were present among the isolated strains. Members of Verrucomicrobia are generally regarded as difficult to isolate and only a few isolated strains are known (Hugenholtz et al., 1998; Sangwan et al., 2005).

On the basis of the taxonomic assignment by the RDP II classifier (Wang et al., 2007) using annotated 16S rRNA gene sequences, 22 strains were most likely members of new bacterial genera or even new orders. In addition, 50 of the strains assigned to the genus level resulted in less than $98.7 \%$ identity with 


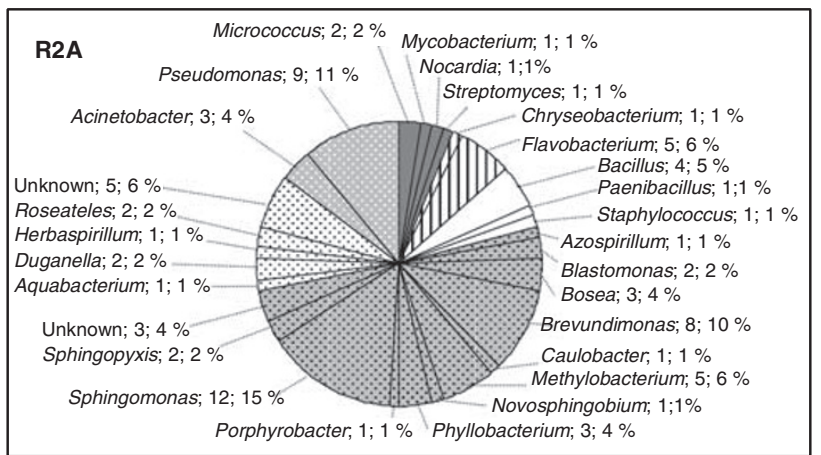

\begin{tabular}{|c|c|}
\hline Actinobacteria: & Firmicutes: \\
\hline Actinobacteria & Bacilli \\
\hline Bacteroidetes: & Proteobacteria: \\
\hline Flavobacteria & Alphaproteobacteria \\
\hline Sphingobacteria & Betaproteobacteria \\
\hline Deinococcus-Thermus: & Gammaproteobacteria \\
\hline Deinococci & \\
\hline
\end{tabular}
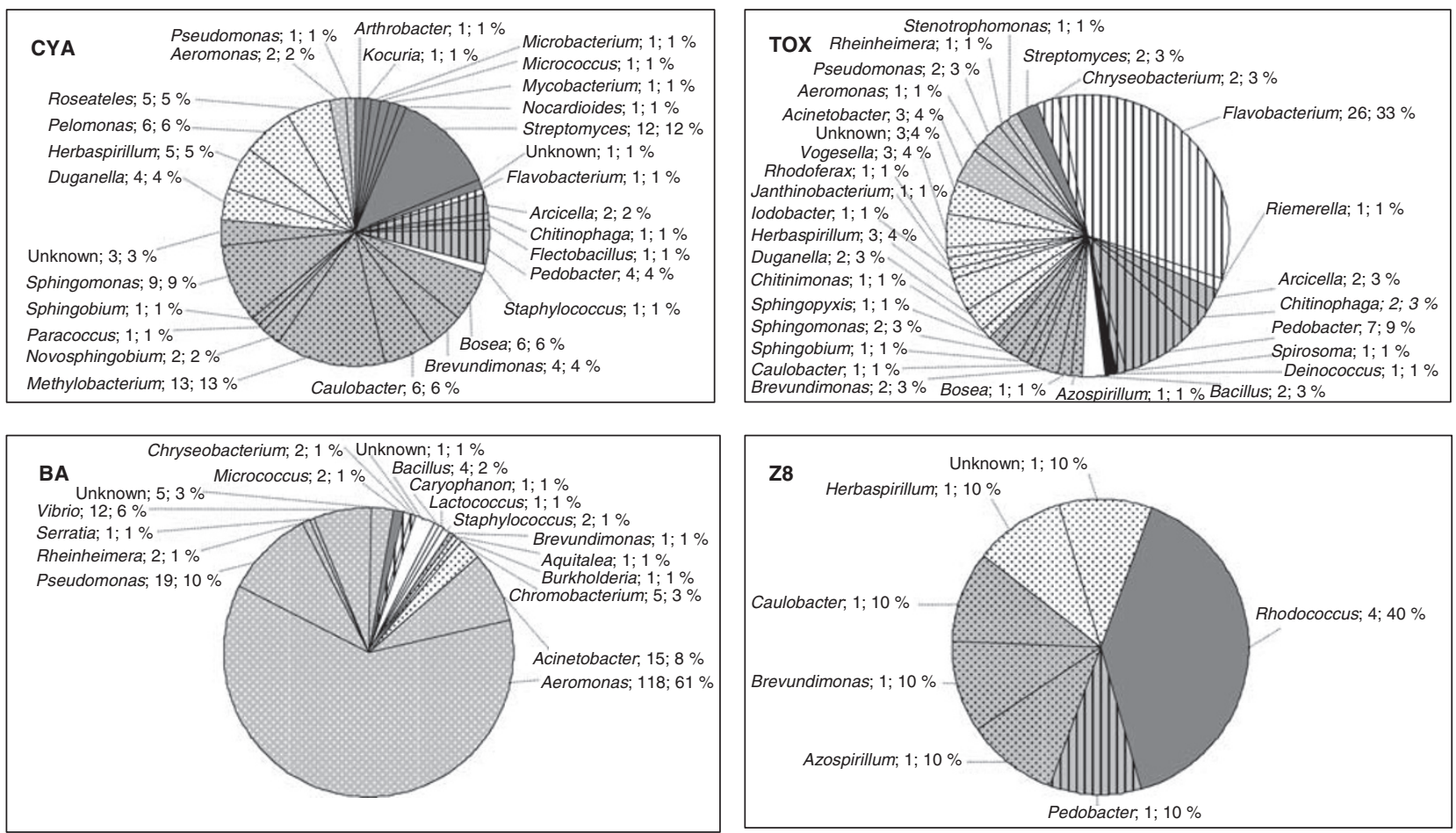

Figure 2 The proportions of taxonomic groups represented by the bacterial stains isolated using different agar media (R2A ${ }^{\mathrm{a}}$, CYA ${ }^{\mathrm{b}}$, $\mathrm{TOX}^{\mathrm{c}}, \mathrm{BA}^{\mathrm{d}}$ and $\mathrm{Z}^{\mathrm{e}}$ ). The sequences of the bacteria were assigned to different phyla, classes and genera using the RDP taxonomic classifier II. A bootstrap value of $80 \%$ was used as the default threshold. The number and percentage of the isolated strains in each genus per isolation medium are shown together with the genus. Altogether 82 strains were isolated from R2A, 97 strains from CYA, 193 strains from BA, 78 strains from TOX and 10 strains from Z8 media. ${ }^{\mathrm{a} C o m m e r c i a l ~ h i g h ~ p r o d u c t i v i t y ~ g r o w t h ~ m e d i u m ~ R 2 A . ~}{ }^{\mathrm{b}} \mathrm{Growth}$ medium that contained Anabaena sp. 748A cell mass for isolating bacteria that may be able to utilize the degrading cyanobacterial biomass for growth. ${ }^{c}$ Growth medium that contained demethyl variants of microcystin RR for enrichment of bacteria that can degrade microcystins. ${ }^{\mathrm{d} C o m m e r c i a l ~ g r o w t h ~ m e d i u m ~ w i t h ~ d e f i b r i n a t e d ~ s h e e p ~ b l o o d ~ f o r ~ e n r i c h m e n t ~ o f ~ h a e m o l y t i c, ~ p u t a t i v e l y ~ p a t h o g e n i c ~ b a c t e r i a . ~}{ }^{\mathrm{e}}$ Minimum growth medium Z8 (Kotai, 1972) for isolating oligotrophic bacteria.

their closest BLAST hits. Currently, 98.7-99.0\% is considered to be the $16 \mathrm{~S}$ rRNA gene sequence similarity threshold between species (Stackebrandt and Ebers, 2006). Therefore, several strains in our culture collection represent the first isolates of bacterial groups that have only been detected based on culture-independent methods. These strains may possess novel functions and their further studies will provide first insights into their role in the environment.

The strains isolated from cyanobacterial water blooms that could be classified only to the class level (strains KU10 and KU14) had close sequence matches to bacterial clones that had earlier been detected from similar environments. The closest match for the alphaproteobacterium KU10 was a clone derived from mesocosm studies designed to mimic small ponds (Horner-Devine et al., 2003). In those studies, it was shown that primary productivity influenced the composition and richness of bacterial communities. The unidentified betaproteobacterium KU14 isolated in this study had a high similarity value with a clone that originated from freshwater bacterioplankton associated with cyanobacterial water blooms in Sweden (Eiler and Bertilsson, 2004). The sequence of the unidentified 
Table 3 The taxonomic distribution of the isolated bacterial strains that inhibited or enhanced growth of the non-toxic strain Anabaena PCC 7122 and the microcystin-producing strain Microcystis PCC 7041

\begin{tabular}{|c|c|c|}
\hline Taxonomic assignment to genus or family & Microcystis & Anabaena \\
\hline \multicolumn{3}{|l|}{ Strains enhancing growth of both cyanobacterial strains } \\
\hline Flavobacterium $^{1}$, Streptomyces ${ }^{1}$, Oxalobacteraceae $^{1}$ & +++ & ++ \\
\hline $\begin{array}{l}\text { Acinetobacter }{ }^{1}, \text { Brevundimonas }^{2}, \text { Duganella }^{1}, \text { Flavobacterium }^{1}, \text { Methylobacterium }^{1}, \text { Pedobacter }^{2} \text {, } \\
\text { Pelomonas }^{1}, \text { Rhodococcus }^{2}, \text { Sphingomonas }\end{array}$ & ++ & ++ \\
\hline Arcicella $^{1}$, Flavobacterium $^{1}$, Herbaspirillum $^{1}$, Methylobacterium $^{1}$ & ++ & + \\
\hline Azospirillum $^{1}$, Bosea $^{1}$, Caulobacter $^{1}$, Spirosoma $^{1}$ & + & ++ \\
\hline Bacillus $^{1}$, Micrococcus $^{1}$ & + & + \\
\hline \multicolumn{3}{|l|}{ Strains inhibiting growth of both cyanobacterial strains } \\
\hline Pedobacter ${ }^{1}$ & - & --- \\
\hline Arthrobacter $^{1}$ & -- & - \\
\hline \multicolumn{3}{|l|}{ Strains enhancing growth of one of the cyanobacterial strains } \\
\hline Caulobacter ${ }^{1}$ & +++ & * \\
\hline 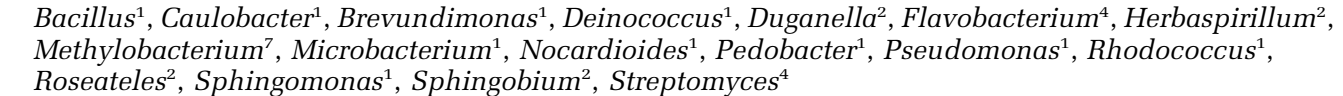 & ++ & * \\
\hline $\begin{array}{l}\text { Aeromonas }^{1} \text {, Arcicella }{ }^{1}, \text { Caulobacter }^{2}, \text { Herbaspirillum }^{2}, \text { Methylobacterium }^{1}, \text { Novosphingobium }^{1} \text {, } \\
\text { Pelomonas }^{3}, \text { Pseudomonas }^{1}, \text { Roseateles }^{2}, \text { Sphingomonas }^{1}, \text { Streptomyces }^{1}\end{array}$ & + & * \\
\hline 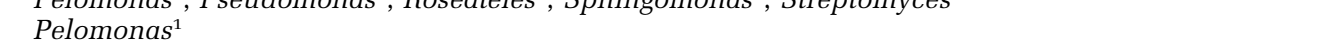 & + & NA \\
\hline Arcicella $^{1}$, Azospirillum $^{1}$, Bosea $^{2}$, Caulobacter $^{1}$, Iodobacter $^{1}$, Rheinheimera $^{1}$ & * & ++ \\
\hline Bosea $^{1}$ & NA & ++ \\
\hline Vogesella $^{1}$ & * & + \\
\hline \multicolumn{3}{|l|}{ Strains inhibiting growth of one of the cyanobacterial strains } \\
\hline Oxalobacteraceae ${ }^{1}$ & -- & * \\
\hline Bacillus $^{1}$, Brevundimonas ${ }^{1}$, Flavobacterium $^{2}$, Pedobacter $^{1}$, Streptomyces ${ }^{2}$ & - & * \\
\hline Sphingomonas $^{1}$ & - & * \\
\hline Flavobacterium $^{2}$ & * & --- \\
\hline Pedobacter ${ }^{1}$ & * & -- \\
\hline Pedobacter $^{2}$ & * & - \\
\hline Flavobacterium $^{2}$, Streptomyces ${ }^{1}$ & * & - \\
\hline \multicolumn{3}{|l|}{ Strains with both enhancing and inhibiting effect on cyanobacterial growth } \\
\hline Herbaspirillum $^{1}$ & +++ & --- \\
\hline Sphingomonas ${ }^{1}$ & - & ++ \\
\hline \multicolumn{3}{|c|}{ 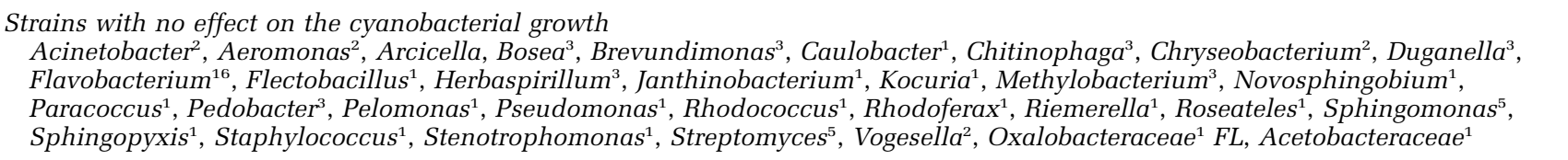 } \\
\hline
\end{tabular}

Genus and family names indicate the closest taxonomic group of the tested strains based on the RDP II classifier results. The number of strains in each group is indicated by the superscript. A bootstrap value of $80 \%$ was used as the classification threshold.

-, cyanobacterial growth inhibited, +, cyanobacterial growth enhanced; - and +, weak inhibiting or enhancing effect on the cyanobacterial growth; -- and ++, clear effect on the growth; --- and +++, strong effect on the growth; ${ }^{*}$ no effect; NA, not analyzed; RDP, Ribosomal Database Project.

alphaproteobacterium TA3A was identical with a clone that had been derived from the human intestine and associated with Crohn's disease (Frank et al., 2007). This clone, in turn, is identical with bacteria detected, for example, in activated carbon filters (unpublished, accession no. AY328843) and drinking water in a distribution system simulator (Williams et al., 2004).

The isolates that could not be assigned to the genus level belonged to five different classes, namely Actinobacteria, Alphaproteobacteria, Betaproteobacteria, Gammaproteobacteria and Flavobacteria. Comparison of the sequences of these strains with the GenBank data showed that the closest matches for most of the strains were derived from earlier uncultured bacteria. The closest matches had been derived from different environments, such as from soils, lakes and river water or sediments, aquatic biofilms, human gastrointestine and fish. The geographic distribution of the closest matches also was high. Sequences had been derived, for example, from arctic lakes in Greenland, lakes of Hawaiian Archipelago and oligo-mesotrophic lakes in Europe.

A large number of haemolytic bacteria were isolated from the water samples that contained cyanobacteria. The presence of potentially pathogenic bacteria might explain some of the adverse human health symptoms after contact with water that contains cyanobacteria, because the symptoms 
reported by exposed persons resemble quite well those caused by opportunistic pathogens that were related to the strains isolated in this study. This should be taken more into consideration when assessing the risks associated with cyanobacterial water blooms. Most of the haemolytic bacteria were affiliated with Aeromonas, which is known to include opportunistic pathogens of humans and animals. Aeromonas is considered to be primarily an aquatic organism and the infections the genus causes are often associated with water contact.

Several Vibrio strains were also haemolytic. All of them originated from the Baltic Sea. Earlier, cyanobacterial blooms have been shown to serve as longterm reservoirs of Vibrio (Islam et al., 2004), but the potential pathogenic features of these bacteria have not been elucidated. The closest sequence match for the strain $4218 \mathrm{~F}$ that could be classified to the Vibrionaceae family level was an isolate classified as a pathogen of fish, Scophthalmus maximus (unpublished, accession no. DQ314527). Haemolytic strains other than Vibrio or Aeromonas were affiliated with genera that are known to contain opportunistic pathogens, such as Pseudomonas, Acinetobacter, Brevundimonas, Streptomyces, Mycobacterium and Bacillus.

On the basis of the 16S rRNA sequences, most of the Vibrio strains had a high similarity value with Vibrio cholerae, the causative agent of cholera and severe infections (Lukinmaa et al., 2006). On the basis of $16 \mathrm{~S}$ rRNA data, several strains were affiliated, for example with the genera Flavobacterium, Sphingomonas, Methylobacterium, Bosea and Herbaspirillum, which are also known to include pathogenic members. However, sequence similarity cannot be used to assess whether the strains are pathogenic or not. Evaluation of that requires further studies, for example characterization of virulence genes of the strains, and clinical experiments.

The majority $(57 \%)$ of the strains isolated from treated drinking water that originated from surface water with frequent occurrence of cyanobacteria belonged to the class Alphaproteobacteria. Sphingomonas was the most common genus. Strains of Sphingomonas and Brevundimonas were isolated from the majority of the purification plants studied (from five out of seven treatment plants) regardless of the different water treatment methods used. In addition, it is noteworthy that a few strains isolated from the treated drinking water were affiliated with genera that are known to contain pathogenic members, such as Mycobacterium, Nocardia, Paenibacillus and Staphylococcus. However, their potential pathogenic features cannot be assessed on the basis of this study.

Most of the strains that were screened either inhibited or enhanced the growth of cyanobacteria. Possible mechanisms may include various types of interactions from nutrient cycling to the production of growth-inhibiting and cell-lysing compounds
(Paerl, 1996; Rashidan and Bird, 2001; Sigee, 2005; Ozaki et al., 2008). The majority of the tested strains enhanced cyanobacterial growth. In earlier studies, heterotrophic bacteria have shown features, such as attachment to cyanobacterial cells, chemotaxis to cyanobacteria and prolonged viability in association with cyanobacteria (Paerl, 1996; Islam et al., 2004; Eiler et al., 2006). In addition, many blooming cyanobacterial species have not been successfully grown as axenic cultures but seem to prefer the presence of other bacteria (Paerl, 1996). Therefore, in general, the associations between cyanobacteria and their accompanying bacteria seem to be mutualistic. In contrast, some heterotrophic bacteria have also been shown to prevent cyanobacterial growth by preying on cyanobacteria or even halting cyanobacterial blooms (Manage et al., 2000; Rashidan and Bird, 2001). The large number of the strains isolated in this study and shown to influence the growth of cyanobacteria provides a solid basis for future studies on the mechanisms behind the inhibition/ enhancement of the cyanobacterial growth by heterotrophic bacteria.

In addition to standard methods, it is important to formulate specific growth media if the aim is to isolate new specific bacteria. Of the growth media used in this study, R2A, CYA and TOX plates seemed to be the most non-selective. More than 20 bacterial genera were isolated from each of them. Thus, these media were the most useful to obtain a general view of the culturable cyanobacteria-associated aquatic bacteria. With the Z8 medium, the number of genera was low. The high proportion of Rhodococcus strains on Z8 agar is in accordance with the oligotrophic nature of several known Rhodococcus strains (Ohhata et al., 2007). The experimental setup in this study did not allow a closer analysis of the specificity of the different growth media. For example, different diversity indices could be applied, but for such studies colonies should be isolated systematically from all growth media, that is either all colonies or a totally randomized set of colonies from all plates. In most cases, we used the morphological or haemolytic features of the colonies as a preliminary selection step to get representatives from as many different bacteria as possible.

The bacterial strains isolated from the TOX medium, especially the Flavobacterium strains, may provide an opportunity to widen the view of bacteria that degrade cyanobacterial hepatotoxins. Earlier, known strains of bacteria that are able to degrade cyanobacterial toxins are mainly members of the family Sphingomonadaceae within the class Alphaproteobacteria and Paucibacter toxinivorans strains of the class Betaproteobacteria (Jones et al., 1994; Park et al., 2001; Saito et al., 2003; Ishii et al., 2004; Rapala et al., 2005; Amé et al., 2006). The presence of such bacteria in water may have an important role in the natural cleansing of the chemically stable hepatotoxins. The putative 
Table 4 Examples of compounds degraded by the strains of the bacterial genera represented among the strains isolated in the study

\begin{tabular}{|c|c|c|}
\hline Degraded compounds & Genus & Reference \\
\hline Alcohols and alkanes & Rhodococcus & $\begin{array}{l}\text { de Carvalho et al. } \\
\text { (2007) }\end{array}$ \\
\hline Biodegradable plastics & Roseateles & Suyama et al. (1999) \\
\hline $\begin{array}{l}\text { Biphenyl and } \\
\text { dibenzofuran }\end{array}$ & Porphyrobacter & Hiraishi et al. (2002) \\
\hline Chitin & Chitinimonas & Chang et al. (2004) \\
\hline $\begin{array}{l}\text { Di-2-ethylhexyl } \\
\text { phthalate }\end{array}$ & Microbacterium & Chen et al. (2007) \\
\hline $\begin{array}{l}\text { Ethyl- and } \\
\text { methylpyridines }\end{array}$ & Arthrobacter & $\begin{array}{l}\text { O'Loughlin et al. } \\
\text { (1999) }\end{array}$ \\
\hline \multirow{5}{*}{$\begin{array}{l}\text { Polycyclic aromatic } \\
\text { hydrocarbons (PAHs) }\end{array}$} & Bacillus & Zhuang et al. (2003) \\
\hline & Micrococcus & Zhuang et al. (2003) \\
\hline & Mycobacterium & Miller et al. (2004) \\
\hline & Novosphingobium & $\begin{array}{l}\text { Suzuki and Hiraishi } \\
(2007)\end{array}$ \\
\hline & Paenibacillus & Daane et al. (2001) \\
\hline Rubber and crude oil & Nocardia & Tsuchii et al. (1997) \\
\hline
\end{tabular}

toxin-degrading bacteria isolated in this study could be used, for example, in purifying contaminated drinking water. However, their abilities to degrade the toxins need to be tested further.

Several strains, for example those affiliated with the genera Sphingomonas, Flavobacterium, Pseudomonas, Nocardia and Paenibacillus, that were isolated in this study are of potential interest as members of these genera are able to degrade complex organic compounds (Table 4). For example, strains of Sphingomonas are known to degrade a variety of slowly degradable compounds, such as phthalate esters (Chang et al., 2004), aromatic hydrocarbons (Zylstra and Kim, 1997) and dibenzofurans (Wilkes et al., 1996). The rich secondary metabolite arsenal produced by cyanobacteria (Harada, 2004) may favour such bacteria.

This study showed that lakes, rivers and brackish waters with frequent cyanobacterial predominance during summer months contained a high diversity of cultivable heterotrophic bacteria. Some of the strains were earlier unknown or uncultured bacteria, and thus taxonomically interesting. Isolation of several bacterial strains with no known close relatives indicates how little is still known about aquatic microbial communities. The bacteria isolated also included potential opportunistic pathogens, which, in addition to cyanobacteria themselves, might be the causative agents of adverse health effects in humans who are exposed to water that contains cyanobacteria. The presence of potentially pathogenic bacteria should be taken into consideration when the risks of cyanobacteria are assessed. Several strains were found that inhibited or enhanced the growth of cyanobacteria, were putative cyanobacterial toxin-degrading bacteria or were affiliated with bacteria that are known to degrade persistent and problematic organic com- pounds. Isolation of such specific bacteria will allow in the future more focused studies on the functions behind and implications of the ecological associations in the aquatic environments.

\section{Acknowledgements}

This work was financially supported by the Academy of Finland (Microbes and Man Research Programme, decision number 202500, to JR; the Centre of Excellence Programme, decision number 53305 and 118637 , to KS and decision number 115400 to CL) and the Finnish Environment Institute. We thank Ms Kaisa Heinonen, Ms Jaana Eskelinen, Ms Minna Madsen, Ms Katri Kosonen, Ms Katariina Kojo and Ms Sarri Uotila for technical assistance.

\section{References}

Altschul SF, Gish W, Miller W, Myers EW, Lipman DJ. (1990). Basic local alignment search tool. J Mol Biol 215: 403-410.

Amé AV, Echenique JR, Pflugmacher S, Wunderlin DA. (2006). Degradation of microcystin-RR by Sphingomonas sp. CBA4 isolated from San Roque reservoir (Córdoba-Argentina). Biodegradation 17: 447-455.

Baek K-H, Kim H-S, Oh H-M, Yoon B-D, Kim J, Lee I-S. (2004). Effects of crude oil, oil components, and bioremediation on plant growth. J Environ Sci Health A 39: 2465-2472.

de Carvalho CCCR, Marques MPC, Fernandes P, da Fonseca MMR. (2007). Degradation of hydrocarbons and alcohols by Rhodococcus erythropolis DCL14: a comparison in scale performance. Biocatal Biotransf 25: $144-150$.

Chang S-C, Wang J-T, Vandamme P, Hwang J-H, Chang P-S, Chen W-M. (2004). Chitinimonas taiwanensis gen. nov., sp. nov., a novel chitinolytic bacterium isolated from a freshwater pond for shrimp culture. System Appl Microbiol 27: 43-49.

Chen J-A, Xiang L, Jun L, Jia C, Zhiqun Q, Quing Z et al. (2007). Degradation of environmental endocrine disruptor di-2-ethylhexyl phthalate by a newly discovered bacterium, Microbacterium sp. strain CQ0110Y. Appl Microbiol Biotechnol 74: 676-682.

Cole JR, Chai B, Farris RJ, Wang Q, Kulam-Syed-Mohideen AS, McGarrell DM et al. (2007). The ribosomal database project (RDP-II): introducing myRDP space and quality controlled public data. Nucleic Acids Res 35(Database issue): D169-D172.

Daane LL, Harjono I, Zylstra GJ, Häggblom MM. (2001). Isolation and characterization of polycyclic aromatic hydrocarbon-degrading bacteria associated with the rhizosphere of salt marsh plants. Appl Environ Microbiol 67: 2683-2691.

Edwards U, Rogall T, Blöcker H, Emde M, Böttger EC. (1989). Isolation and direct complete nucleotide determination of entire genes. Characterization of a gene coding for $16 \mathrm{~S}$ ribosomal RNA. Nucleic Acids Res 17: 7843-7853.

Eiler A, Bertilsson S. (2004). Composition of freshwater bacterial communities associated with cyanobacterial blooms in four Swedish lakes. Environ Microbiol 6: 1228-1243. 
Eiler A, Olsson JA, Bertilsson S. (2006). Diurnal variations in the auto- and heterotrophic activity of cyanobacterial phycospheres (Gloeotrichia echinulata) and the identity of attached bacteria. Freshw Biol 51: 289-311.

Falconer IR, Humpage AR. (2005). Health risk assessment of cyanobacterial (blue-green algal) toxins in drinking water. Int J Environ Res Public Health 2: 43-50.

Frank DN, St. Amand AL, Feldman RA, Boedeker EC, Harpaz N, Pace NR. (2007). Molecular-phylogenetic characterization of microbial community imbalances in human inflammatory bowel diseases. Proc Natl Acad Sci USA 104: 13780-13785.

Giovannoni SJ, Stingl U. (2005). Molecular diversity and ecology of microbial plankton. Nature 437: 343-348.

Harada K-i. (2004). Production of secondary metabolites by fresh water cyanobacteria. Chem Pharm Bul 52: 889-899.

Havens KE. (2007). Cyanobacteria blooms: effects on aquatic ecosystems. In: Hudnell KH (ed). Cyanobacterial Harmful Algal Blooms: State of the Science and Research, vol. 619. Springer: New York, pp 675-732.

Hedlund BP, Gosink JJ, Staley JT. (1997). Verrucomicrobia div. nov., a new division of the bacteria containing three new species of Prosthecobacter. Antonie van Leeuwenhoek 72: 29-38.

Hiraishi A, Yonemitsu Y, Matsushita M, Shin YK, Kuraishi H, Kawahara K. (2002). Characterization of Porphyrobacter sanguineus sp. nov., an aerobic bacteriochlorophyll-containing bacterium capable of degrading biphenyl and dibenzofuran. Arch Microbiol 178: $45-52$.

Horner-Devine MC, Leibold MA, Smith VH, Bohann BJM. (2003). Bacterial diversity patterns along a gradient of primary productivity. Ecol Lett 6: 613-622.

Hugenholtz P, Goebel BM, Pace NR. (1998). Impact of culture-independent studies on the emerging phylogenetic view of bacterial diversity. J Bacteriol 180: 4765-4774.

Ishii H, Nishijima M, Abe T. (2004). Characterization of degradation process of cyanobacterial hepatotoxins by a Gram-negative aerobic bacterium. Water Res 38: 2667-2676.

Islam MS, Mahmuda S, Morshed MG, Bakht HBM, Khan MNH, Sack RB et al. (2004). Role of cyanobacteria in the persistence of Vibrio cholerae O139 in saline microcosms. Can J Microbiol 50: 127-131.

Jones GJ, Bourne DG, Blakeley RL, Doelle H. (1994). Degradation of the cyanobacterial hepatotoxin microcystins by aquatic bacteria. Nat Toxins 2: 228-235.

Karjalainen M, Engström-Öst J, Korpinen S, Peltonen H, Pääkkönen J-P, Rönkkönen S et al. (2007). Ecosystem consequences of cyanobacteria in the Northern Baltic Sea. AMBIO 36: 195-202.

Kerters K, De Vos P, Gillis M, Swings J, Vandamme P, Stackebrandt E. (2006). Introduction to the Proteobacteria. In: Dworkin M, Falkow S, Rosenberg E, Schleifer K-H, Stackebrandt E (eds). The Prokaryotes, A Handbook of the Biology of Bacteria, Volume 5: Proteobacteria: Alpha and Beta Subclasses, 3rd edn. SpringerVerlag: New York, pp 3-37.

Kolmonen E, Sivonen K, Rapala J, Haukka K. (2004). Diversity of cyanobacteria and heterotrophic bacteria in cyanobacterial blooms in Lake Joutikas, Finland. Aquat Microb Ecol 36: 201-211.

Kotai J. (1972). Instructions for Preparation of Modified Nutrient Solution Z8 for Algae. Norwegian Institute for Water Research: Blindern, Oslo, Norway, Publication B-11/69, 5p.

Lahti K, Niemi MR, Rapala J, Sivonen K. (1998). Biodegradation of cyanobacterial hepatotoxins-characterisation of toxin degrading bacteria. In: Reguera B, Blanco J, Fernández ML, Wyatt T (eds). Harmful Algae, Proceedings of the VIII International Conference of Harmful Algae. Xunta de Galicia and Intergovernmental Oceanographic Commission of UNESCO: Santiago de Compostela, Spain, pp 363-365.

Lukinmaa S, Mattila K, Lehtinen V, Häkkinen M, Koskela M, Siitonen A. (2006). Territorial waters of the Baltic Sea as a source of infections caused by Vibrio cholerae non-O1, non-O139: report of 3 hospitalized cases. Diagn Microbiol Infect Dis 54: 1-6.

Manage PM, Kawabata Z, Nakano S-I. (2000). Algicidal effect of the bacterium Algaligenes denitrificans on Microcystis spp. Aquat Microb Ecol 22: 111-117.

Massa S, Caruso M, Trovatelli F, Tosques M. (1998). Comparison of plate count agar and R2A medium for enumeration of heterotrophic bacteria in natural mineral water. J Microbiol Biotechnol 14: 727-730.

Miller CD, Hall K, Liang YN, Nieman K, Sorensen D, Issa B et al. (2004). Isolation and characterization of polycyclic aromatic hydrocarbon-degrading Mycobacterium isolates from soil. Microb Ecol 48: 230-238.

Ohhata N, Yoshida N, Egami H, Katsuragi T, Tani Y, Takagi H. (2007). An extremely oligotrophic bacterium, Rhodococcus erythropolis N9T-4, isolated from crude oil. J Bacteriol 189: 6824-6831.

Oliver RL, Ganf GG. (2000). Freshwater blooms. In: Whitton BA, Potts M (eds). The Ecology of Cyanobacteria, Their Diversity in Time and Space. Kluwer academic Publisher: Dordrecht, The Netherlands, pp 149-188.

O’Loughlin EJ, Sims GK, Traina SJ. (1999). Biodegradation of 2-methyl, 2-ethyl, and 2-hydroxypyridine by an Arthrobacter sp. isolated from subsurface sediment. Biodegradation 10: 93-104.

Ozaki K, Ohta A, Iwata C, Horikawa A, Tsuji K, Ito E et al. (2008). Lysis of cyanobacteria with volatile organic compounds. Chemosphere 71: 1531-1538.

Paerl HW. (1996). Microscale physiological and ecological studies of aquatic cyanobacteria: macroscale implications. Microsc Res Tech 33: 47-72.

Park H-D, Sasaki Y, Maruyama T, Yanagisawa E, Hiraishi A, Kato K. (2001). Degradation of the cyanobacterial hepatotoxin microcystin by a new bacterium isolated from hypertrophic lake. Environ Toxicol 16: 337-343.

Rapala J, Berg KA, Lyra C, Niemi RM, Manz W, Suomalainen S et al. (2005). Paucibacter toxinivorans gen. nov., sp. nov., a bacterium that degrades cyclic cyanobacterial hepatotoxins microcystins and nodularin. Int J Syst Evol Microbiol 55: 1563-1568.

Rashidan KK, Bird DF. (2001). Role of predatory bacteria in the termination of a cyanobacterial bloom. Microb Ecol 41: 97-105.

Rouhiainen L, Sivonen K, Buikema WJ, Haselkorn R. (1995). Characterization of toxin-producing cyanobacteria by using an oligonucleotide probe containing a tandemly repeated heptamer. $J$ Bacteriol 177: 6021-6026.

Saito T, Okano K, Park H-D, Itayama T, Inamori Y, Neilan BA et al. (2003). Detection and sequencing of the microcystin LR-degrading gene, $m l r A$, from new bacteria isolated from Japanese lakes. FEMS Microbiol Lett 229: 271-276. 
Sangwan P, Kovac S, Davis KER, Sait M, Janssen PH. (2005). Detection and cultivation of soil Verrucomicrobia. Appl Environ Microbiol 71: 8402-8410.

Sigee D. (2005). Freshwater Microbiology. Biodiversity and Dynamic Interactions of Microorganisms in the Aquatic Environment. John Wiley \& Sons: Chichester, UK, pp 328-338.

Sivonen K, Jones G. (1999). Cyanobacterial toxins. In: Chorus I, Bartram J. (eds). Toxic Cyanobacteria in Water: A Guide to Their Public Health Consequences, Monitoring and Management. E \& FN Spon: London, pp 41-111.

Stackebrandt E, Ebers J. (2006). Taxonomic parameters revisited: tarnished gold standards. Microbiol Today 33: 152-155.

Suzuki S, Hiraishi A. (2007). Novosphingobium naphthalenivorans sp. nov., a naphthalene-degrading bacterium isolated from polychlorinated-dioxin-contaminated Environments. J Gen Appl Microbiol 53: 221-228.

Suyama T, Shigematsu T, Takaichi S, Nodasaka Y, Fujikawa S, Hosoya $\mathrm{H}$ et al. (1999). Roseateles depolymerans gen. nov., sp. nov., a new bacteriochlorophyll a-containing obligate aerobe belonging to the b-subclass of the Proteobacteria. Int $J$ Syst Evol Microbiol 49: 449-457.

Tsuchii A, Takeda K, Tokiwa Y. (1997). Degradation of the rubber in truck tires by a strain of Nocardia. Biodegradation 7: 405-413.
Wang QG, Garrity M, Tiedje JM, Cole JR. (2007). Naïve bayesian classifier for rapid assignment of rRNA sequences into the new bacterial taxonomy. Appl Environ Microbiol 73: 5261-5267.

Webster NS, Wilson KJ, Blackall LL, Hill RT. (2001). Phylogenetic diversity of bacteria associated with the marine sponge Rhopaloeides odorabile. Appl Environ Microbiol 67: 434-444.

Wilkes H, Wittich R-M, Timmis KN, Fortnagel P, Francke W. (1996). Degradation of chlorinated dibenzofurans and dibenzo-p-dioxins by Sphingomonas sp. strain RW1. Appl Environ Microbiol 62: 367-371.

Williams MM, Domingo JW, Meckes MC, Kelty CA, Rochon HS. (2004). Phylogenetic diversity of drinking water bacteria in a distribution system simulator. J Appl Microbiol 96: 954-964.

Zhuang W-Q, Tay J-H, Maszenan AM, Krumholz LR, Tay ST-L. (2003). Importance of Gram-positive naphthalene-degrading bacteria in oil-contaminated tropical marine sediments. Lett Appl Microbiol 36: 251-257.

Zwart G, Crump BC, Kamst-van Agterveld MP, Hagen F, Han S-K. (2002). Typical freshwater bacteria: an analysis of available $16 \mathrm{~S}$ rRNA gene sequences from plankton of lakes and rivers. Aquat Microb Ecol 28: 141-155.

Zylstra GJ, Kim E. (1997). Aromatic hydrocarbon degradation by Sphingomonas yanoikuyae B1. J Ind Microbiol Biotechnol 19: 408-414.

Supplementary Information accompanies the paper on The ISME Journal website (http://www.nature.com/ismej) 